\title{
SERPINA1 Gene
}

National Cancer Institute

\section{Source}

National Cancer Institute. SERPINA1 Gene. NCI Thesaurus. Code C105010.

This gene plays a role in both coagulation and the regulation of proteolysis. 